\title{
ARCHAEOLOGICAL RESEARCHES AND ARCHAEOLOGICAL EXHIBITIONS IMPLEMENTED BY THE NATIONAL MUSEUM KRUŠEVAC BETWEEN 2009 AND 2012
}

\begin{abstract}
Within 2009-2012 Kruševac National Museum has organized research on five sites and organized eight archeological exhibitions (by authors and guests). Initiative activities for commencement of construction works on the reconstruction of he central building of Kruševac National Museum in Lazar's Town during 2010 included protective archeological researches of the close Museum building surrounding. During the research the layers dating from neolith to late Middle age were found. Not even this time, the researchers of Lazar's Town were able to note layers belonging to the ancient period. Multi discipline research of Mojsinje-Poslon Mountains involved systematic research on three localities-Ukosa and Kućiste in Grad Stalać, Municipality of Ćićevac (2009, 2010 and 2011) and Branik in Dedina near Kruševac (2010 and 2011). On the site of Ukosa the remains of Early Byzantium highland fortress from the 6th century were found together with the layers dating from prehistoric and antique period and horizons from the $10^{\text {th }}$ and $11^{\text {th }}$ century $A D$. The Existence of the Neolithic settlement was proved on the Branik locality. Researches on these three sites are to continue in 2012. Archeological research on the locality Bedem in the village of Maskare, Municipality of Varvarin, three campaigns took place within 2009-2011. The remains of Early Byzantium lowland fortress from the $6^{\text {th }}$ century were brought to the light wherefrom the foundation of the monumental basilica remains were defined. Prehistoric layers have been determined on the researched site. The researches realized within the project supported by the Ministry of Culture will be continued in 2012.
\end{abstract}

Keywords: archaeological research, exhibitions, Kruševac National Museum, Ukosa and Kućiste Grad Stalać, Lazarev grad - Kruševac, Bedem, Branik.

In the period from 2009 to 2012, the National Museum Kruševac implemented archaeological researches on five localities and organized eight archaeological exhibitions (by authors and hosted). The archaeological researches were implemented under the projects supported by the Ministry of Culture of the Republic of Serbia.

The archaeological researches were performed on the localities of Lazar's town in Kruševac, Ukosa and Kućiste in Grad Stalać, Bedem in Maskare and Branik in Dedina.

The campaign of the archaeological researches on Lazar's town was implemented in 2010, as part of the preparatory work for the implementation of the project of reconstruction and renovation of the main building of the National Museum Kruševac. These reasons have caused the excavation to be directed to the location in the immediate vicinity of the Museum 
building. The researches were performed within the project supported by the Ministry of Culture.

Before the large campaign of the archaeological researches of Lazar's town in Kruševac, which was conducted during the seventh decade of the $20^{\text {th }}$ century, the only known elements of the former Serbian capital were the Lazarica church and the remains of the Donjon tower (Keep), with the traces of town wall (Ковачевић 1980: 13 - 28). An architect Aleksandar Deroko had tried to reconstruct the appearance of the medieval fortress, but due to the scarcity of data, he only managed to take an attempt of the Donjon tower (Keep) reconstruction (Дероко 1950: 122).

The archaeological researches have provided an overview of the capital city of the Serbian prince, the definition of the town wall direction and the ascertainment of the existence of forty buildings within it. A movable archeological material provided an insight into everyday life of Prince Lazar's courtiers, through records of ceramics, jewelry, glass, craft tools, tools and weapons.

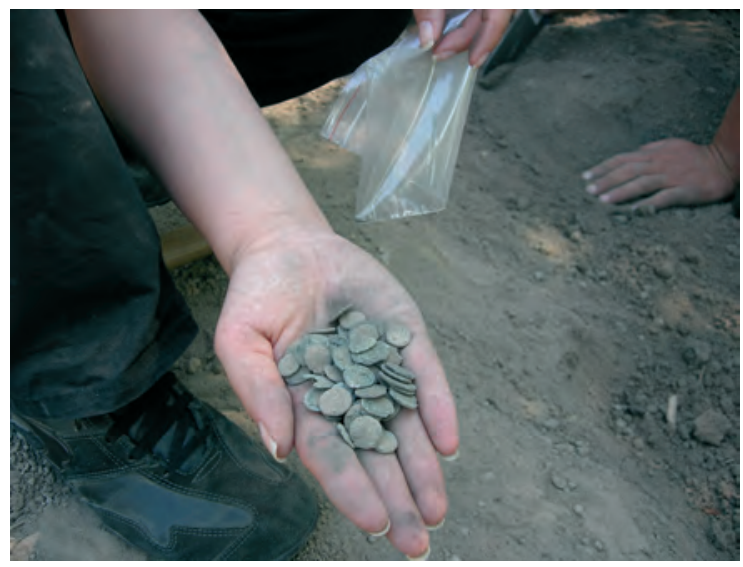

Fig. 1 Part of the hoard of the Roman coins from Ukosa (photo: Dušan Rašković)

The excavations showed that the locality had been populated for the first time in the Neolithic period. That the continuity of populating was rarely interrupted is confirmed with the records from the Bronze and the Iron Age, remains from the Antique and the Early Byzantine period, whereas there are strong indications of the existence of the medieval settlement, older than the large construction project by Prince Lazar.

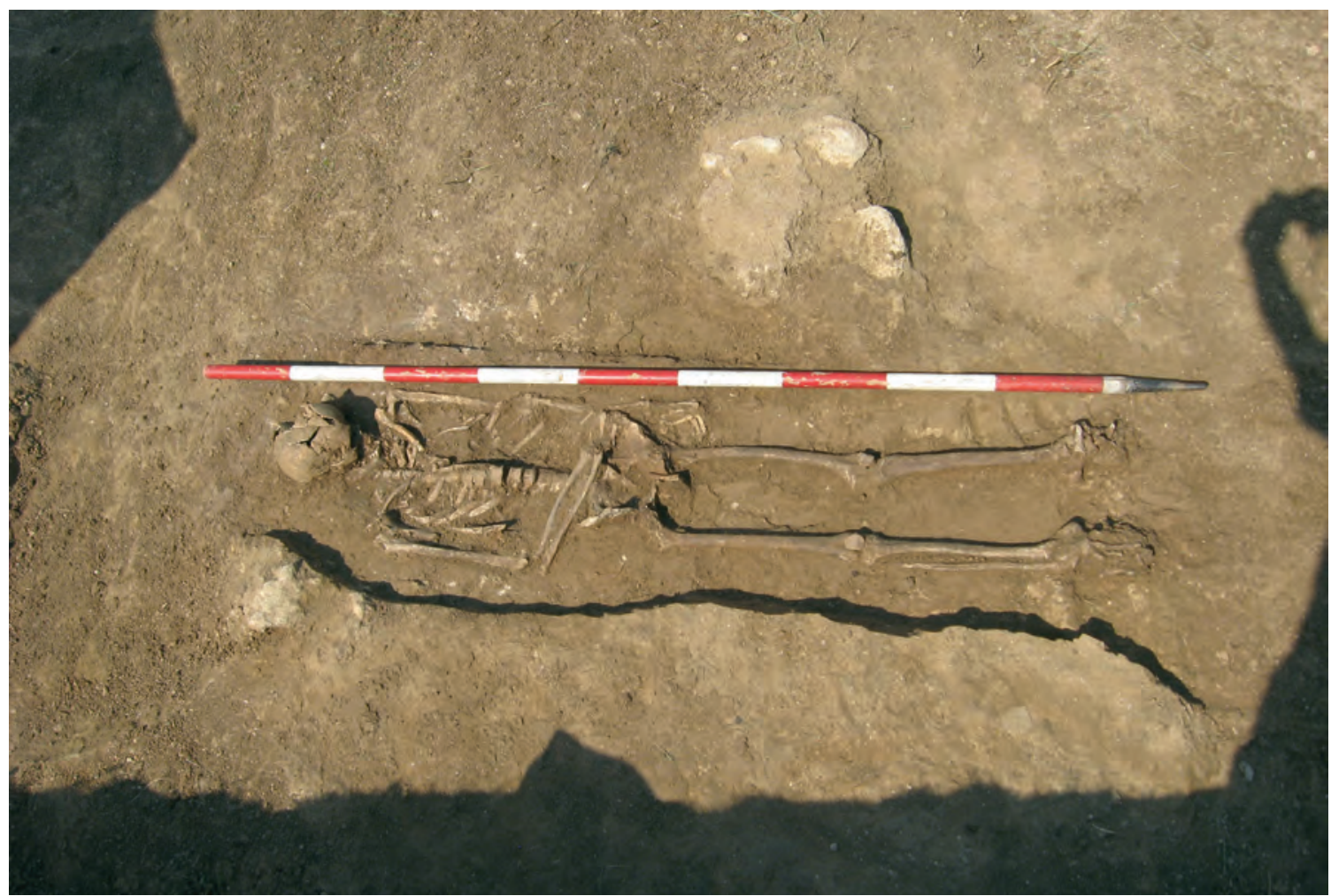

Fig. 2 Ukosa - record of a pitcher (photo: Dušan Rašković) 


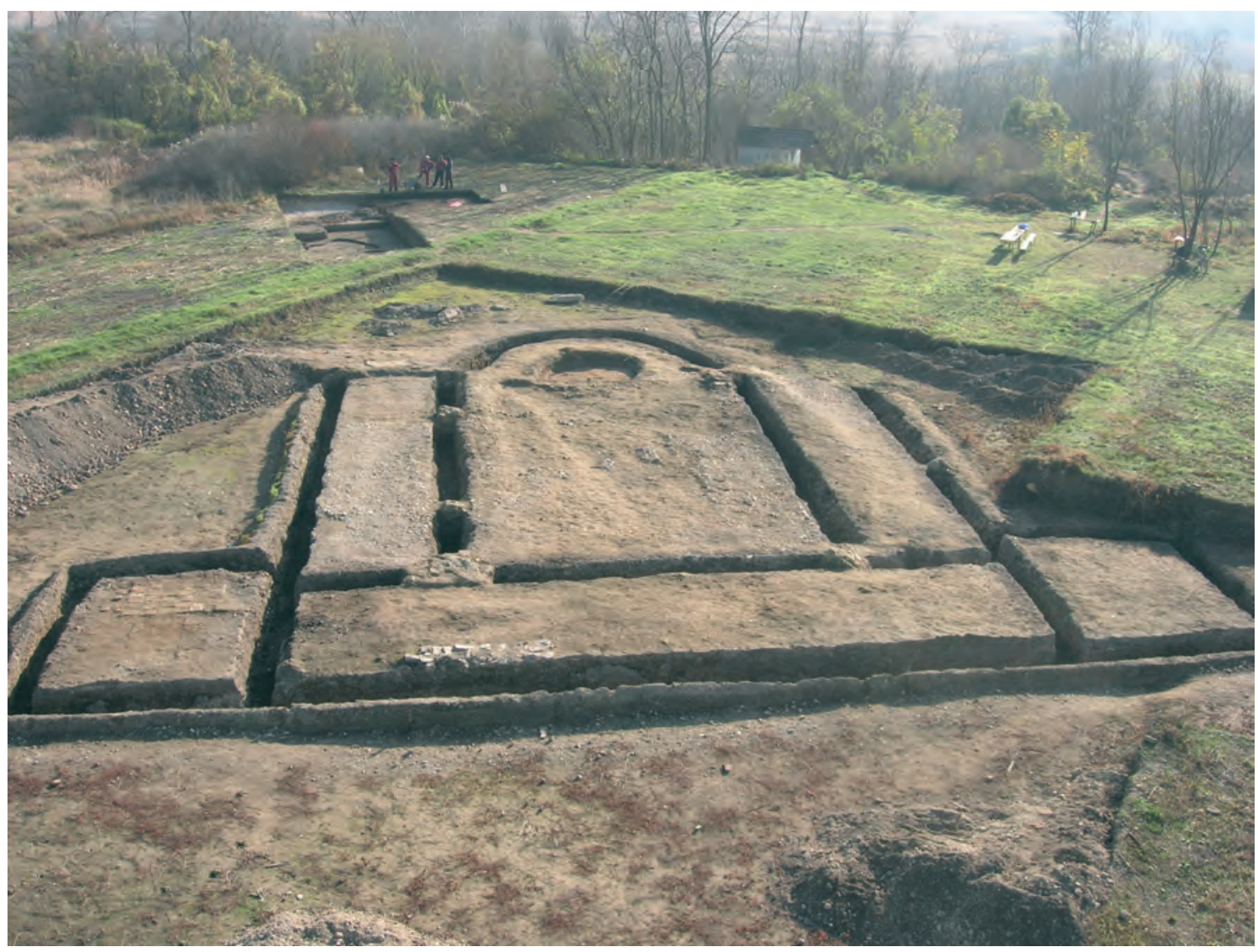

Fig. 3 Ukosa - part of the town wall (photo: Dušan Rašković)

The Prince Lazar's capital city was built on slightly elevated river terrace, about two kilometres distant from the West Morava and one kilometre from the Rasina. Along the town wall there was a Kožetin stream running, allowing the water supply in case of siege.

It catches one's eye that the city was not built on strategically dominant and protected place, so

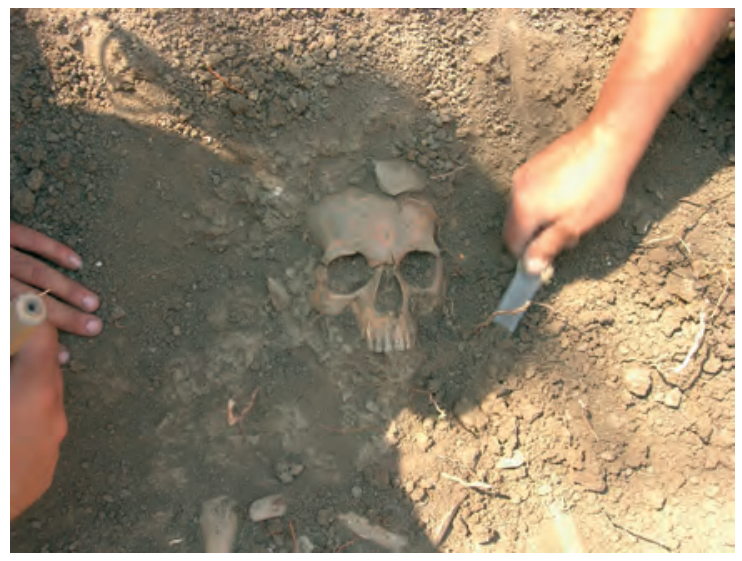

Fig. 4 Kućiste - skeletal grave of a female individual (photo: Dušan Rašković) that it is obvious that the military-strategical reasons were not the prevalent one on the location choice, which is a novice for the Serbian medieval towns, for whose locations hardly reachable places were usually chosen.

It becomes clear that the place characterized by some other conveniences was chosen as the location for the new capital. An overview of the road

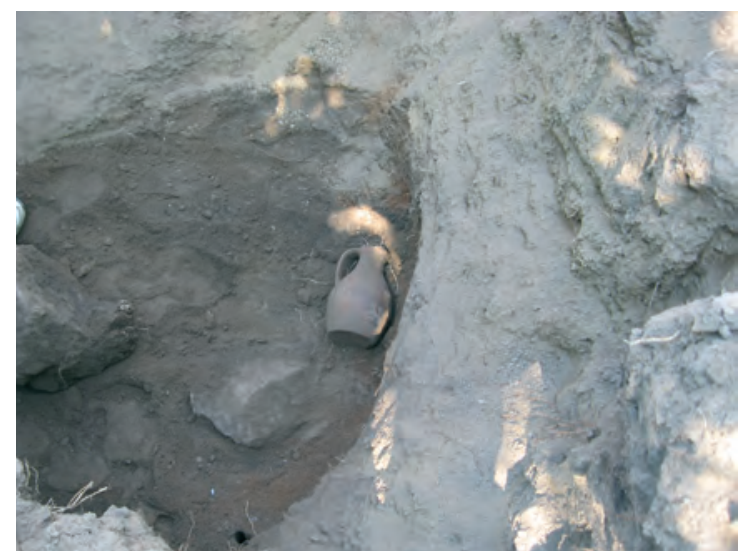

Fig. 5 Ukosa - discovery of skeletal grave (photo: Dušan Rašković) 


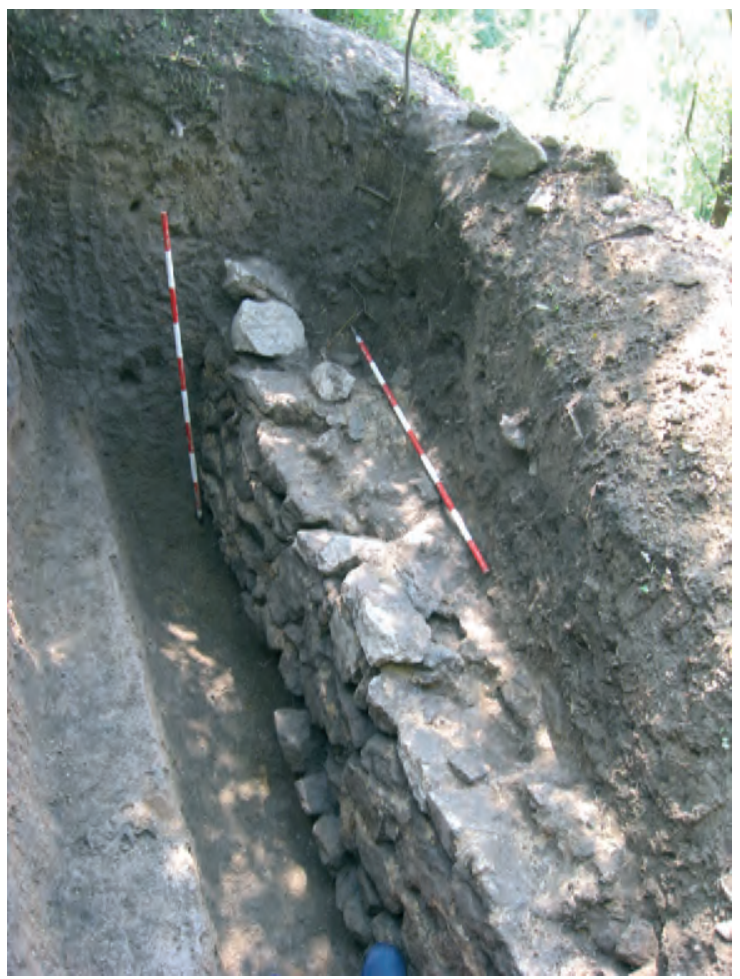

Fig. 6 Basilica in Maskare (photo: Marin Bugar)

network and positions of the other medieval towns and church centres in the late $14^{\text {th }}$ century show that this place was a significant intersection of medieval roads (Бошковић 1980: 9, fig. 1).

Everything indicates that the capital of Moravian Serbia was meant to be economical and cultural centre, built on a place that was busy, but at the same time slightly drawn inside and additionally protected, by defensive walls of the medieval Stalać, from the Constantinople Road, being an important, but still endangered communication.

There were the two construction phases of building Lazar's town determined. First, the Small town was fortified with the walls made of pebbles, protected with the ditch and the Donjon tower (Keep). Then, with the town walls made of crushed stone, an entire plateau was protected and the fortification was formed, oriented towards northwest - southeast, the approximate dimensions being 300 x 200 metres

Thus, a space which can be divided into two units was determined. The Small and the Big town. The Small town, meant to be the last line of defense of the entire fortification, was located in the northeastern, the lowest part of the complex and covered the space of not more than $1600 \mathrm{~m}^{2}$ (Миладиновић 2006: 2 - 3).

The town walls of the Big town had shallow foundations (to $25 \mathrm{~cm}$ deep) and an average width of about two metres. Those walls were fortified with the towers, built on a mutual distance of 35 - 50 metres. In front of two towers were found the remains of the outer protective walls, having the same direction as the towers, with which they were not joint.

It can be assumed that these are the town's double walls remains, recorded in the description of Kruševac from the $15^{\text {th }}$ century by the French travel writer Bertrandon de la Broquiere. The travel writer, speaking of Kruševac, states: „And that borough is very small and very well fortified with the double wall, which is torn down at its top where the crenels are, and there was another very small town, which is now ruined“(Broquiere (Брокијер) 1950: 127).

In the centre of the Big town was built the Church of St Stephen - the Lazarica Church, an endowment of Prince Lazar. Although not of big dimensions, Lazarica is significant as a church building in which all the elements of the Moravian architecture are united. Not far from the Lazarica Church, on the highest point of the plateau, are the remains of a group of the profane buildings, among which are distinguishing the objects identified in literature as the palace and the horse stable.

The southern and the eastern part of the medieval fortification have remained largely unexplored, due to the exploration being unable because of the existence of contemporary buildings. Probes opened on this part of the town have shown the existence of the town wall on a presumed route and a part of the defensive tower (Ковачевић 1980: 34).

The buildings built within the fortification were not organically joint with town walls, but stood alone in this space, which is another indicator of the new time which, in spite of the constant positions to relate it to the famous epoch of the Nemanjić dynasty, presents the first act of the last drama of the Serbian Middle Ages, known as Moravian Serbia.

The campaign of the archaeological researches on Lazar's town was implemented in 2010, as part of the preparatory work for the 


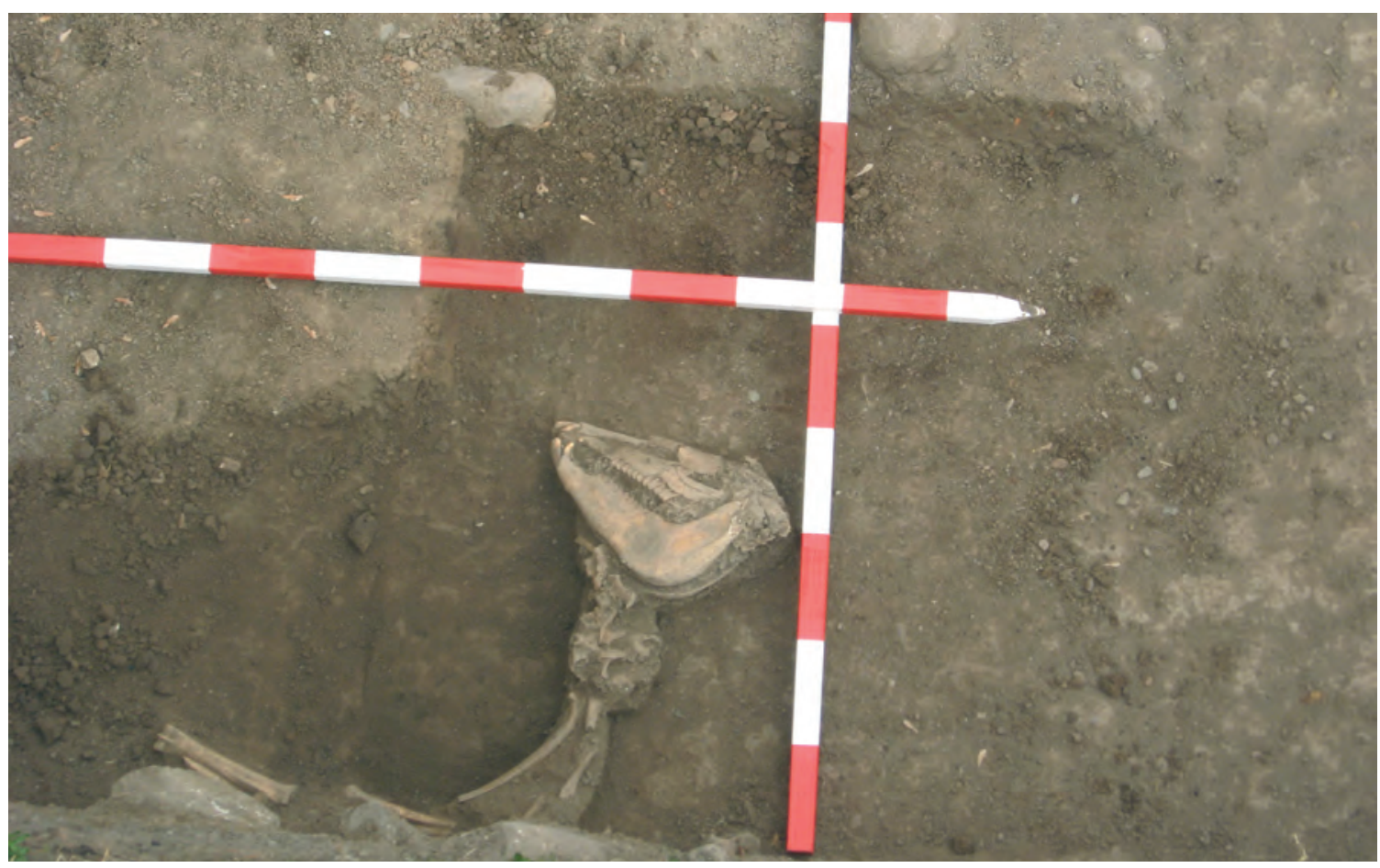

Fig. 7 Lazar's town - part of the horse skeleton (photo: Ljubiša Vasiljević)

implementation of the project of reconstruction and renovation of the main building of the National Museum Kruševac. These reasons have caused the excavation to be directed to the location in the immediate vicinity of the Museum building. The researches were performed within the project supported by the Ministry of Culture. The research coordinator was Ljubiša Vasiljević, while the expert team consisted of Sanja Rutić, Dušan Rašković, Nataša Miladinović and Milan Trifunović.

The continuity of populating in the prehistoric period, from the Starčevo culture, was confirmed during the research through the records from the Copper, the Bronze and the Iron Age. Not any remains or records from the Antique or the Early Byzantine period were found on the explored place. The existence of smaller buildings from the $14^{\text {th }}$ century, as well as of the layers timely placed into the $15^{\text {th }}$ and the $16^{\text {th }}$ century was confirmed.

The attention is drawn by the unusual records of the three horse skeletons, carefully laid on the exact distance of five metres between each other. A movable archeological material, discovered in the vicinity of the skeletons, is dated in the $15^{\text {th }}$ and the $16^{\text {th }}$ century. The most characteristi- cal are the records of the stone cannonballs and the large pieces of metal castings. Records of the larger pieces of metal could present the remains of the activities related to the cannon casting, which is the typical procedure for the time period in question. This record is surely in relation to a certain historical event related to the area of Kruševac (Васиљевић, Рутић 2013: 68 - 69).

The researches on Lazar's town have been continued in 2012 and are still ongoing.

As a part of the multidisciplinary research on Mojsinje and Poslon mountains by the National Museum Kruševac during archeological campaigns between 2009 and 2012, researches have been directed to the localities of Ukosa and Kućiste in Grad Stalać, in the municipality of Ćićevac. The localities are situated in the southern part of Grad Stalać, immediately above the local road Grad Stalać - Stevanac, that means above the left bank of the South Morava. The research coordinator was Dušan Raškovic, while the expert team consisted of Sanja Rutić, Ljubiša Vasiljević, Nataša Miladinović and Milan Trifunović.

Ukosa is a multilayer locality which had been populated for the first time in the period of the Early Iron Age and was being used until the 


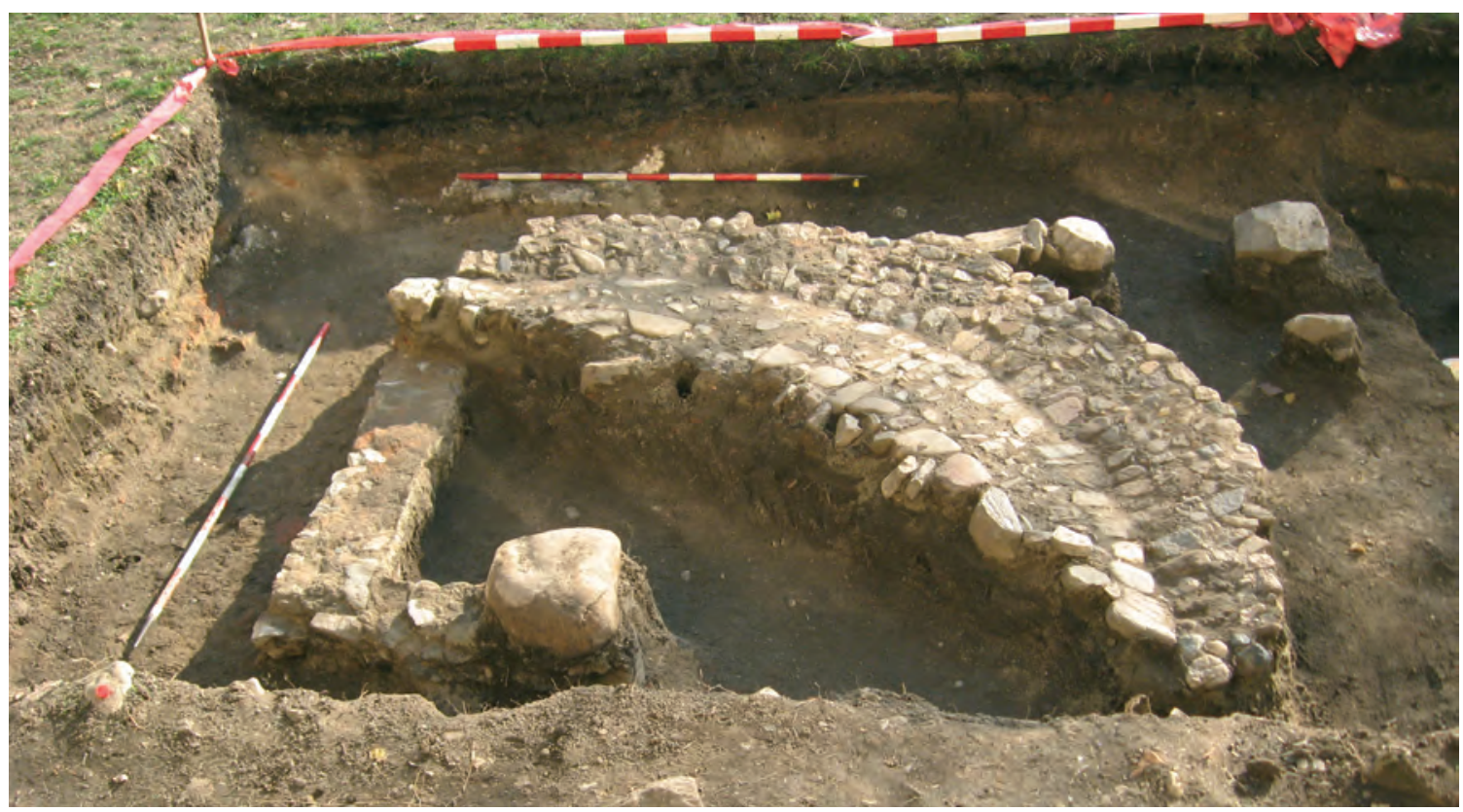

Fig. 8 Lazar's town - semicircular construction made of stone (photo: Sanja Rutić)

Roman conquest of the area, at the beginning of the movable archaeological material dating from the New Era. In the $4^{\text {th }}$ century, the strategic benefits of Ukosa were re-used, what is evidenced with the records of the Roman bronze coins. The wave of renovation of fortifications in the Balkans, during the reign of Justinian (525 - 565), did not bypass even Ukosa, what is evidenced with the discovered remains of the town wall and the Early Byzantine period, when the fortification had had the most significant role.

One of the most significant records from the localities which were known before the beginning of the systematic archaeological researches, is the Langobardian „S“ fibula, a unique record on the territory of Serbia. The fibula suggests the

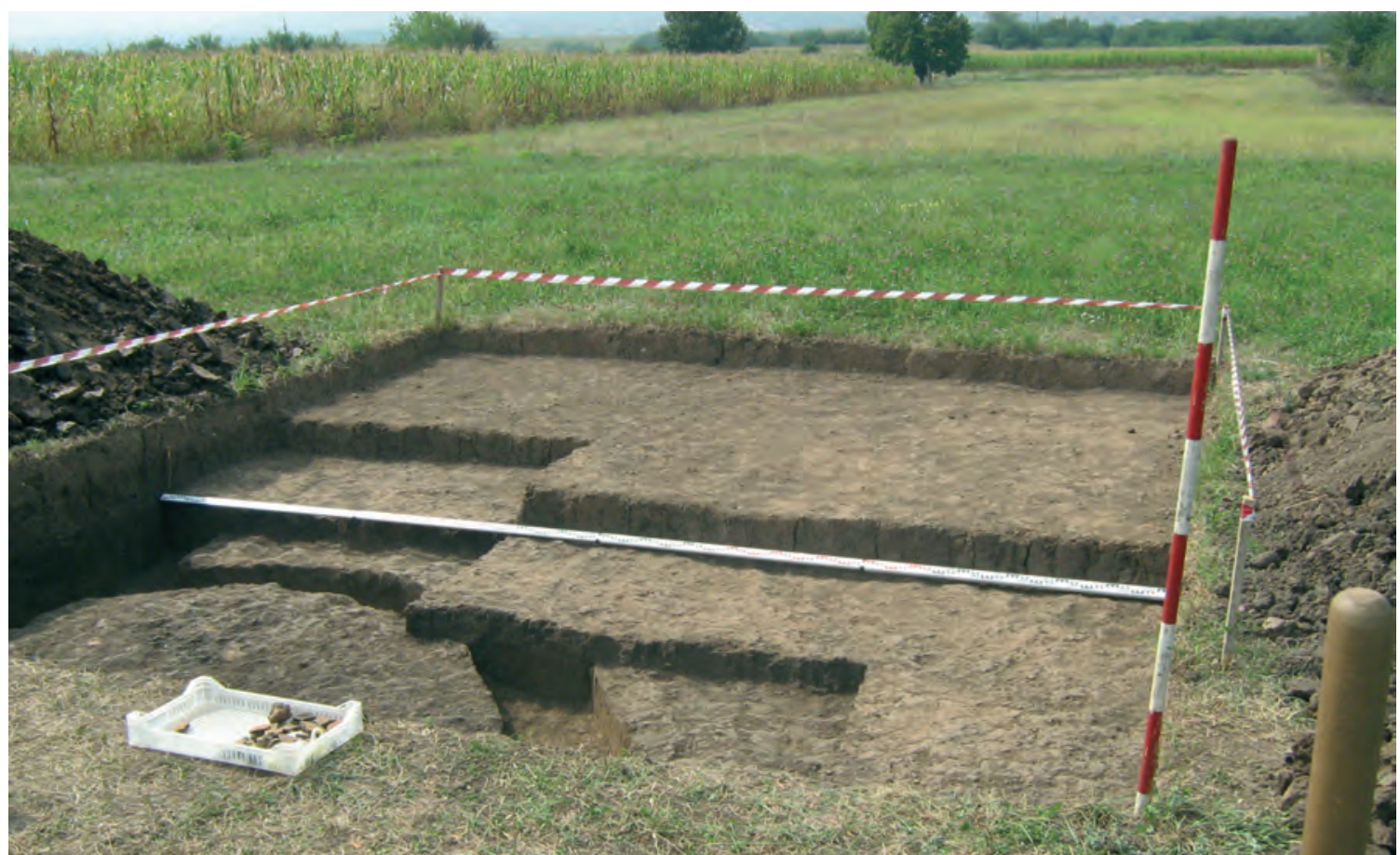

Fig. 9 Locality Branik in Dedina (photo: Ljubiša Vasiljević) 


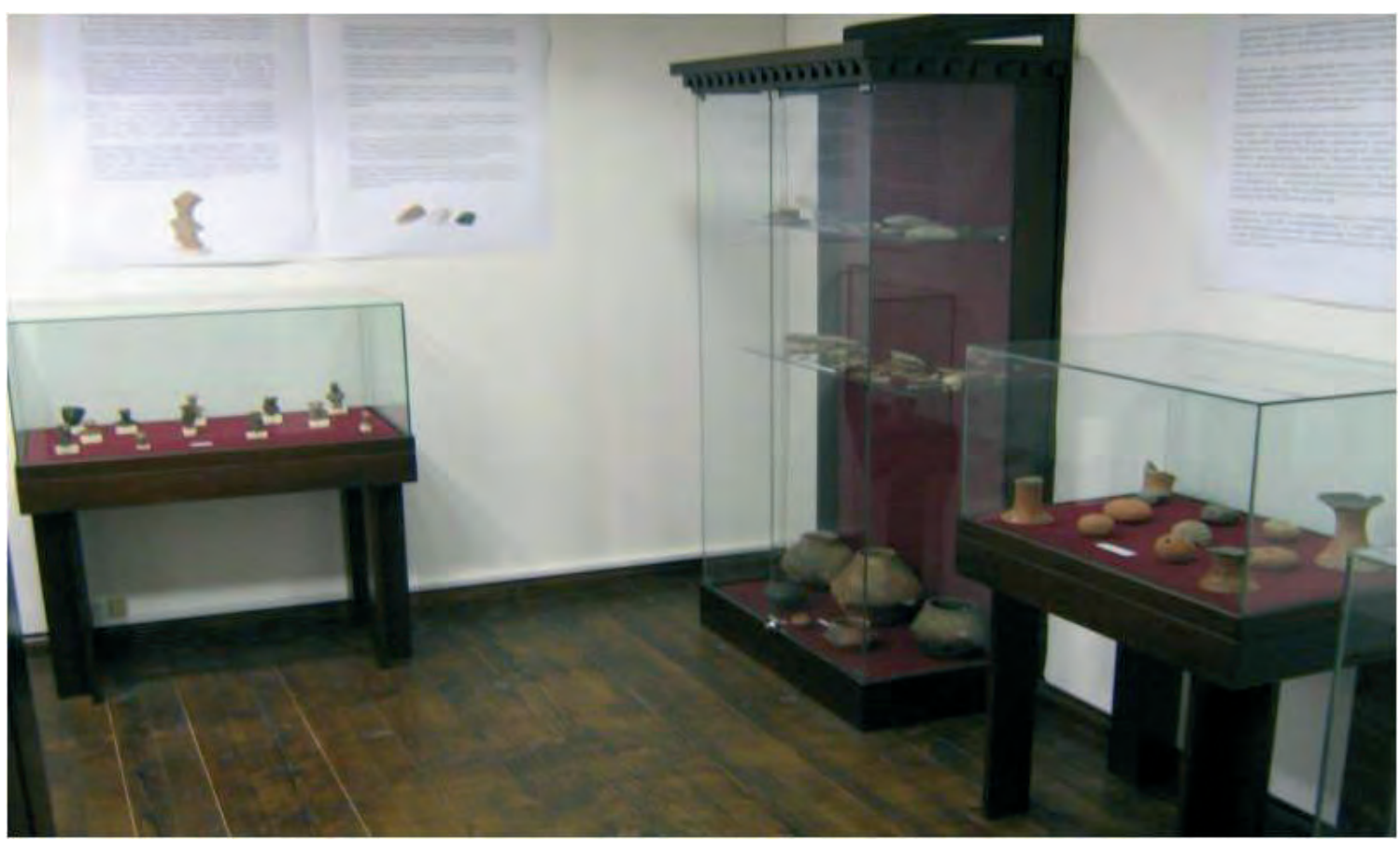

Fig. 10 Exhibition detail „Neolithic settlement at Stragare“ (photo: Ljubiša Vasiljević)

possibility that the fortification crew consisted of Langobards in the $6^{\text {th }}$ century.

Through the archaeological researches, the discovered were the parts of the town walls, the preserved height of $1.10 \mathrm{~m}$. The wall's width was not ascertained. The town wall had been built using the larger pieces of the rough stone, joint with mortar. The wall line follows the configuration of the hilly terrain. The length of the fortification is almost $300 \mathrm{~m}$, while the width dimensions vary between 80 and $100 \mathrm{~m}$. An area of the fortification is a natural cascade divided into four plateaus (Рашковић 2002: 51).

In the middle part of the fortification the four caves were discovered, dug under the rock surface. The caves had primarily had the function of the food storage. Numerous records of amphorae in the very caves and their immediate surrounding are the evidence that this place had been a space for storing the food. It is certain that, at some point, this space had lost this purpose and, as it is usually the case, it began to be used as a place for the disposal of unnecessary things, which enabled for the numerous objects to wait until they are reached by the archaeologist's spatula.
The most attractive record from the campaign in 2011 is the hoard of coins. There were 115 coins found, mostly in small denominations, dated in the second half of the $4^{\text {th }}$ century. There was also found a large number of coins dated in the $6^{\text {th }}$ century.

One of the so-called trap holes is particularly characteristical for the material found in it. Ceramics from this hole indicates the continuation of life in the fortification after the $8^{\text {th }}$ century and indicates the presence of Slavs in the fortification. During the period from the $9^{\text {th }}$ to the $11^{\text {th }}$ century, the Balkans were the battlefield for Serbia, Bulgaria and Byzantium, and the fortifications on the river Morava had to regain their significance. The discoveries made during the researches performed in 2012 could also be in relation with these records. Ceramics and the metal records discovered on that occasion are determined to belong to the period of $9^{\text {th }}-10^{\text {th }}$ century and can be related to the period of Bulgarian domination over this area (Рашковић 2011: 7 - 8).

An anthropological analysis of the skeletons found on Kućiste showed that the decomposed remains of a female individual about 25 years old had been found in the grave. The relative height of this individual was $163-170 \mathrm{~cm}$. With a high certainty, 
it could be claimed that this person had suffered from bone tuberculosis in her life, but whether this disease was the direct cause of death can not be confirmed with certainty (Џомба 2011: 281 - 283).

The archaeological locality Bedem extends at the periphery part of the village Maskare, on about 15 kilometres northern from Kruševac and opposite of the medieval town Stalać. It is situated a few hundred metres from where the West Morava meanders in the great arc and near to the confluence of the West Morava and the South Morava. The large early Byzantine fortification from the 6th century was discovered on this place. The dimensions of the fortification are $130 \times 130$ metres.

The locality Bedem in the village Maskare was explored during the four campaigns conducted from 2009 to 2012. It is an Early Byzantine fortification which had controlled the place where the two rivers, the South Morava and the West Morava, meet and together form the Great Morava. Fortifications of this type had controlled roads that were leading down the river valleys. The Turkish Moravian river fleet was based on this place in the $15^{\text {th }}$ and the $16^{\text {th }}$ century.

It is for these reasons that one of the most significant fortifications of the medieval Serbia had been built in Grad Stalać, which lies exactly opposite the Bedem, on the opposite bank of the West Morava. It should be emphasized here, that near to the Grad Stalać there is a locality Ukosa, contemporaneous with Bedem, with which it had probably formed the control system. With the locality Ukosa we have already met in this article. The locality Bedem had drawn attention of the explorers even in the late $19^{\text {th }}$ century.

The first to write about Bedem was $\mathrm{S}$. Braljinac, who noted that „The ruins are lying on a plateau above the Morava and the sides are forming a square, whose every side is about 100 $\mathrm{m}$. The thickness of the surrounding walls is more than one metre. Except the walls forming the said square, there are some more squares inside, and some of them are with the rounded corners. Beside this there are some driven channels which seem to lead to the deepness. The bricks are mixed, the small and the big ones. The small ones are common, like ours today, and the big ones are 35 long, 29 wide, and $4 \mathrm{~cm}$ thick. Of the things, they told me that a few years before, there had been found a piece of one iron tripod (sadžak) and a piece of sabre, and of the money, one gold coin 10 years before and one bronze coin, which, they said, had been sent to Belgrade“ (Браљинац 1890: 57).

The locality has also been visited by $\mathrm{M}$. Riznić, one of the Serbian archaeology pioneers. Riznic states that the dimensions of the fortification are $156 \times 132 \mathrm{~m}$, and that the fortification was built of stone and bricks, with twelve projecting towers of $18 \mathrm{~m}$ of the distance between each other, the walls thickness of $1.25 \mathrm{~m}$. Dimensions of the bricks, which were recorded by Riznić, are identical to the dimensions specified in Braljinac's writings (Ризнић 1891: 71 - 91).

In his anthropogeographical study on Temnić, issued in 1905, S. Mijatović states the following about the fortification in Maskare: „The town was excavated 15 years ago. Today it is highly ruined, and later the same was scattered through the village for the houses raising“ (Мијатовић 1905: 344)

Before the beginning of the systematic archaeological researches, the archaeologists of the museum of Kruševac were repeatedly conducting the field survey, where they found tegulae, bricks and fragments of ceramics. The particularly characteristical are the records of the bricks with the decorations shaped as smaller crosses. There were the tales of the locals recorded that the skeleton graves had been found in the eastern part of the fortification. According to D. Rašković and N. Đokić, these graves originate from the Middle Ages (Рашковић, Ђокић 1997: 137).

The National Museum Kruševac, with shorter interruptions, has been conducting the systematic archaeological researches of the locality Bedem since year 2001. Starting from 2010, the researches were conducted within the project supported by the Ministry of Culture, in cooperation with the Institute of Archeology in Belgrade. During the period covered with this work, the archaeological researches of the locality Bedem were coordinated by Vujadin Ivanišević on behalf of the Archaeological Institute, and Marin Bugar on behalf of the National Museum Kruševac. Members of the expert team were Nataša Miladinović and Gordana Čađenović. 
The first results of the archaeological excavations show that this is a multi-layer locality. Besides the Byzantine material, there was also found a material form the prehistoric period from the Eneolithic (Baden cultural group), Middle Bronze Age (Vatin cultural group), the Early Iron Age - Iron Age I (Brnjica cultural group) and the Late Iron Age (Чађеновић 2011: 40).

It was determined that the real dimensions of the Early Byzantine fortification are 130 $\mathrm{x} 130$ metres. The locality belongs to the rare type of the Early Byzantine fortifications built in the lowland, because in those troubled times the most often chosen locations were on naturally protected elevations. Relatively shallow cultural layer indicates that it was not for long in function. Absence of traces of fire, as well as the small number of movable archaeological records, indicate that the fortification had been left at some moment not preceded by the military conflict in the immediate surrounding.

Within the fortification, the particularly outstanding is the record of the triple-naved basilica whose dimensions, length and width, exceed 23 metres, making it one of the most monumental on the territory of the entire Serbia. (Бугар 2012: 5 - 6).

Of the movable archaeological records from the Early Byzantine period, the significant are the records of ceramics, arrowheads, tools, knives, wedges and money (the half folles of Justin II).

That this space has also served as a temporary refuge in the following centuries evidences a record of the residential building, area of about 25 square metres, within which there was a pearlike furnace with brick paving. The residential building is dated in the $10^{\text {th }}$ century. (Бугар 2012: 5 - 6).

A prehistoric locality Branik in Dedina was registered in 1997. The surface records has already indicated the possibility that on this place had been a kind of „workshop“ for manufacturing of the stone tools in the Neolithic period (Рашковић 2000: 15). It is situated 3 kilometres northeastern from Kruševac and 3.5 kilometres southeastern from the mouth of the Rasina into the West Morava.

The locality is situated on the gentle slope descending down the Mojsinje mountains to- wards the alluvial plains of the Rasina and the West Morava. Archaeological researches of the localities were performed in 2011 within the implementation of the Project of multidisciplinary researches of Mojsinje - Poslon complex. The researches have shown that the locality had been populated in the Neolithic period, which means the period of Starčevo culture. The researches were coordinated by Milan Trifunović and Gordana Čađenović.

The finding site is specific for its location and the surface area. Its dimensions are considerably less than those of the similar localities and are about 50 x 50 metres. It is located far from any greater watercourses and wellsprings, without natural protection, which did not make ideal conditions for Neolithic settlement forming.

The discovered movable archeological material also differs from other contemporaneous finding sites by the representation of the records. The most common are the records of flint tools and tools made of polished stone. On the very surface of the terrain, grouped on relatively small area, there is a high concentration of the flint material, presented not only in the finished products (blades, microliths, small knives, scrapers...), but also in the intermediate products, refuse, as well as in the flint cores on which there are traces of the partial exploitation. The very frequent are also the records of the supporting tools used for making flint tools. These are the polished chisels, tongue-as-blade axes and mauls - striker with the circular section. The very significant characteristic for defining the finding site purpose in the Neolithic period is the very weak presence of ceramics records. The ceramics found belongs to the Starčevo culture. (Чађеновић, Трифуновић 2012: 5).

The presence of a small number of ceramics fragments is a confirmation of the hypothesis that the locality Branik is not an example of a classical Neolithic settlement, but that the role of this place was primarily that of a workshop, which means that it was a centre intended for the manufacturing of flint and stone tools.

In the exhibition space of the Small showroom of the House of the Simic family the follow- 
ing exhibitions were opened: „Neolithic settlement at Stragari“ (from the Museum collection of the National University Trstenik) (author: Ljubiša Vasiljević, expert assistant: Sanja Rutić), „Antique Horreum Margi“ - in cooperation with the Museum Horreum Margi - Ravno from Ćuprija (authors: Ljubiša Vasiljević, Danica Milošević Jović, expert assistant: Sanja Rutić) „The Cult of Mithras in the confluence zone of three Moravas" (authors: Dušan Rašković, Ljubiša Vasiljević), „Zindan - Roman settlement Praesidium Pompei“ - in cooperation with the Heritage Museum Aleksinac (authors: Dušan Rasković and Aleksandar Nikezić) and „Jerina's town near Trstenik“ - in cooperation with the Institute for Protection of Cultural Monuments Kraljevo and the Association of citizens Jerina's town (realization of the exhibition: Marija Marić, Ljubiša Vasiljević, Sanja Rutić and Vojkan Milovanović).

Within exhibitions „Brothers Music“ (author: Ljubiša Vasiljević) and „Battle of Kosovo“ (author: Sanja Rutić) organized as a part of Vidovdan celebrations, the archaeological material was also displayed, as an illustration of the epoch presented in the exhibition.

Within exhibitions „Brothers Music“ (author: Ljubiša Vasiljević) and „Battle of Kosovo“ (author: Sanja Rutić) organized as a part of Vidovdan celebrations, the archaeological material was also displayed, as an illustration of the epoch presented in the exhibition.

\section{BIBLIOGRAPHY}

\section{Бошковић, Ђ. 1980}

Место Крушевца у систему утврђених градова средњовековне Србије, Археолошка истраживања Крушевиа и Моравске Србије, ур. Ђурђе Бошковић,Археолошки институт, Народни музеј Крушевац, Београд: 7-12.

Браљинац, С. 1890

Допис из Крушевца, Старинар VII, Српско археолошко друштво, Београд: 57.

\section{Брокијер, де ла Б. 1950}

Путовање преко мора, Научна књига, Београд.

\section{Бугар, М. 2012}

Бедем - Маскаре, у: Археологија у сликама, ур. Љубиша Васиљевић, Народни музеј Крушевац, Крушевац: 6-7.

\section{Чађеновић, Г. 2011}

Енеолитски слој на локалитету Бедем у Маскару, Српско археолошко друштво XXXIV годишґи скуп, програм, извештаји u апстракти, ур. Душан Михаиловић и Војислав Филиповић, Краљево.

\section{Чађеновић, Г., Трифуновић, М. 2012}

Браник - Дедина, у: Археологија у сликама, ур. Љубиша Васиљевић, Народни музеј Крушевац, Крушевац, 4.

\section{Дероко, А. 1950}

Средњовековни градови у Србији, Црној Гори и Македонији, Просвета, Београд.

\section{Џомба, Д. 2011}

Антрополошка анализа скелета са Укосе, Крушевачки зборник 15, Народни музеј Крушевац, Крушевац, 281 - 289.

\section{Ковачевић, М. 1980}

Профана архитектура средњовековног Крушевца - Резултати досадашњих истраживања, Археолошка истраживаға Крушевиа и Моравске Србије, ур. Ђурђе Бошковић, Археолошки институт, Народни музеј Крушевац, Београд: 13-30.

\section{Мијатовић, М. С. 1905}

Темнић - Антропогеографска студија, Српски етнографски зборник кьига шеста, Насеља српских земаља, књига III, Српска краљевска академија, Београд.

\section{Миладиновић, Н. 2006}

Средњовековни Крушеваи - профана архитектура Лазаревог града, Народни музеј Крушевац, Замак културе - Културни центар Врњачке Бање, Врњачка Бања.. 


\section{Рашковић, Д. 2000}

Антички археолошки локалитети на подручју генералног плана Крушевца 2021. године, Крушевачки зборник 5/6, ур. Драган Рашковић Народни музеј Крушевац, Крушевац: 9-24.

\section{Рашковић, Д. 2002}

Антички археолошки локалитети и комуникације у ширем крушевачком окружју, у: Трећа Југословенска конференција византолога, ур. Љ. Максимовић, Н. Радошевић, Е. Радуловић, Византолошки институт - Народни музеј Крушевац, Београд - Крушевац: 29-73.

Рашковић, Д. 2011

Утврђење Укоса у Град Сталаћу, Народни музеј Крушевац, Крушевац.

\section{Рашковић, Д., Ђокић, Н. 1997}

Резултати рекогносцирања античких налазишта и комуникација на подручју јужног Темнића, Гласник Српског археолошког друштва 13, Српско археолошко друштво, Београд: 135146.

\section{Ризнић, М. 1891}

Старине у планини Мојсињу и околини, Старинар VIII, Српско археолошко друштво, Београд, $51-91$.

Васиљевић, Љ., Рутић, С. 2013

Археолошка истраживања Лазаревог града у Крушевцу - кампања из 2010. године, Српско археолошко друштво - XXXVI Скупштина u годишњи скуп - програм, извештаји и апстракти, ур. Војислав Филиповић и Драгана Антоновић, Нови Сад: 68 - 69.

\section{REZIME}

\section{ARHEOLOŠKA ISTRAŽIVANJA I ARHEOLOŠKE IZLOŽBE REALIZOVANE OD STRANE NARODNOG MUZEJA KRUŠEVAC U PERIODU OD 2009-2012. GODINE}

Ključne reči: Arheološka istraživanja, arheološke izložbe, Narodni muzej Kruševac, Ukosa i Kućište - Grad Stalać, Lazarev grad - Kruševac, Bedem, Branik.

U periodu od 2009-2012. godine Narodni muzej Kruševac realizovao je arheološka istraživanja pet lokaliteta i priredio osam autorskih arheoloških izložbi. Arheološka istraživanja izvedena su u okviru projekata podržanih od strane Ministarstva kulture Republike Srbije. Pripremni radovi pred realizaciju projekta rekonstrukcije i adaptacije centralne zgrade Narodnog muzeja Kruševac u Lazarevom gradu, tokom 2010. godine, uključivala su i arheološka istraživanja neposrednog okruženja zgrade. Iskopavanja su pokazala postojanje kulturnih slojeva od starijeg neolita do poznog srednjeg veka. Nisu pronađeni slojevi iz antičkog perioda. U okviru Projekta multidisciplinarnih istraživanja Mojsinjsko - poslonskog kompleksa, arheološki su istražena tri lokaliteta - Ukosa i Kućište u Grad Stalaću, Opština Ćićevac (2009, 2010 i 2011 godine) i Branik u Dedini, Grad Kruševac (2010 i 2011. godine). Na lokalitetu Ukosa su, pored nalaza vezanih za značajno ranovizantijskog utvrđenja iz VI veka, otkriveni tragovi naseljavanja iz starijeg gvozdenog doba i latena, antički nalazi i horizonti iz X - XI veka nove ere. Neolitsko naselje starčevačke kulture iskopavano je na lokalitetu Branik. Arheološka istraživanja lokaliteta Bedem u Maskaru, Opština Varvarin, na svetlo dana iznela su ostatke nizijskog utvrđenja iz VI veka sa ranohrišćanskom bazilikom, kao i slojeve iz eneolita, bronzanog doba, starijeg gvozdenog doba i latena.

Tokom pomenutog vremenskog okvira, Narodni muzej Kruševac priredio je osam autorskih arheoloških izložbi, organizovao gostovanje izložbe iz fondova Muzeja Grada Beograda, dok 
su, u okviru istorijske izložbe „Kosovska bitka“, izlagani i arheološki nalazi kao ilustracija i svedočanstvo opisane epohe. 